\title{
An empirical study to find important factors on building national brand: An Iranian tourism case study
}

\author{
Abolghasem Hakimipour ${ }^{a}$ and Hamed Bozorgkho ${ }^{b^{*}}$
}

${ }^{a}$ Department of Management and Accounting, AllameTabatabaei University, Tehran, Iran

${ }^{b}$ Department of Management, Alborz non-for-profit educational university, Qazvin, Iran

\begin{tabular}{|c|c|}
\hline A R T I C L E I N F O & A B S T R A C T \\
\hline $\begin{array}{l}\text { Article history: } \\
\text { Received May 20, } 2012 \\
\text { Received in Revised form } \\
\text { July, 29, } 2012 \\
\text { Accepted } 15 \text { August } 2012 \\
\text { Available online } \\
\text { 21 August } 2012 \\
\text { Keywords: } \\
\text { Brand } \\
\text { Tourism industry } \\
\text { National brand }\end{array}$ & $\begin{array}{l}\text { Building national brand plays an important role on today's economy to attract interested tourists } \\
\text { in visiting various countries. There are different factors impacting national brand such as } \\
\text { advertisement, natural attraction, etc. In this paper, we perform an empirical investigation to } \\
\text { find the impact of ten most important factors on building brand. The study designs and } \\
\text { distributes a questionnaire among } 384 \text { international tourists who visited Iran during the year of } \\
2010 \text { and it uses factor analysis to group important factors. The results extract four groups; the } \\
\text { first factor includes three most important components including satellite advertisement } \\
\text { programs, public awareness on economical power and public awareness on specialized } \\
\text { symposium and conferences. The second factor includes three other important factors, which } \\
\text { are public awareness on human right, advertisement programs through distribution brushers and } \\
\text { internet advertisement. The third factor includes two variables, which are public awareness on } \\
\text { education and access to educational services and introducing cultural heritage. Finally, the last } \\
\text { factor includes introducing natural attraction and advertisement programs through distribution } \\
\text { brushers. }\end{array}$ \\
\hline
\end{tabular}

\section{Introduction}

There are many evidences to believe that globalization plays an important role in today's world and all countries must create their own brands for introducing their identities to others (Aaker, 1991; Aaker, 1996; Aaker, 1997; Aaker \& Shansby, 1982; Kleppe et al., 2002; Keller, 2008; Pike, 2009). People try to build value added brand for their identities to attract more tourist to their countries (Gilmore, 2002; Lodge, 2002; Mathieson \& Wall, 1982) and governmental agencies play essential role on introducing countries' image to other people in various around the world (Harrison, 2002; Morgan et al., 2002). These attempts are accomplished to help economy and eventually builds good image for countries (Starr, 2001; Hall, 2002). National brand plays an important role on countries' identities.

* Corresponding author. Tel: +989123713933

E-mail addresses: hamed_uni@yahoo.com (H. Bozorgkho) 
There are many evidences to analyze the impact of issues happened after September 11 accident in Iraq and Afghanistan and to find out how much of 18 trillion dollars value of national brand in United States has been jeopardized (Kra, 2002).

Target marketing is one of the most important ways for introducing a combination of various cities and locations for tourists as a package (Hall, 2002; Mill \& Morrison, 1992). Target marketing includes two important performance measures including identification and distinction (Florek, 2005). There are literally various factors for promoting tourism industry such as image, word of mouth, etc. (Baloglu \& Brinberg, 1997; Kapferer, 1996). Cai (2002) introduced brand identification and brand image as two important factors for promoting brand. However, there are some contradictions in such definition discussed by Florek (2006). Nevertheless, a good image from a particular city, village or a country creates a value (Ryan \& Gu, 2008). Baloglu and McCleary (1999) introduced a model of destination image formation. Paswan et al. (2003) investigated nation branding loyalty towards the country, the state and the service brands. There are literally different studies, which indicate that a comprehensive image from a country's brand is built through evaluating all aspects of the country (Baloglu, 1996; Baloglu \& Mangaloglu, 2001; Baloglu \& McCleary,1999).

Zarabi and Ahmadi (2012) presented a study for ranking different cities and villages in province of Isfahan based on analysis of social indicator during the statistic period 1996-2006. They explained that one of the primary governmental concerns is to understand the level of economical and social development in different locations of a country. Understanding social and economical characteristics of different cities help provide necessary assistance for underdeveloped areas and promote some value added activities such as tourism in better-developed areas. They presented an empirical study based on Factor Analysis to rank different towns, villages and cities located in city of Isfahan, Iran in terms of various socio-economical criteria. The study gathered necessary information from 1996 to 2007. The results of the survey indicate that three cities of Feridan, Nayeen and Falavarjan are in the best position in terms of different social and cultural criteria while Lenjan, Barkhar and Mymehand Isfahan are located in the worst positions.

Tabrizi et al. (2012) explained that many countries compete to gain political, economic, social and cultural advantages. In addition, cities are trying to demonstrate their predominance on local and regional levels and achieve development by using managerial science. Meetings, incentives, conventions and exhibitions tourism (MICE) hosting as a significant element of urban tourism is one of the effective methods to obtain urban development around the world. However, no specialized planning and independent investments in regard to these activities have been organized in Iran. Aiming to identify suitable areas in the northern part of Iran, they tried to recognize the necessary physical and location related (P.L) indexes to perform the specialized activities of MICE tourism in this region. They first identified indispensable indicators to accept special role of MICE tourism and then they adapted some areas based on GIS and fuzzy method. Their result map showed that a ribbonlike area near the Caspian Sea with two wide lands at central and western parts was a proper choice to host MICE activities in the region from the viewpoint of P.L indexes.

In this study, we use factor analysis to detect important factors influencing building brand in Iran. The organization of this paper first presents details of the survey in section 2. Section 3 presents details of the study and finally concluding remarks are given in the last to summarize the contribution of the paper.

\section{The proposed study}

The proposed study of this paper considers the effects of the following items on domestic brand.

1. Introducing natural attraction has positive influence on building domestic brand (En).

2. Public awareness on human right has positive influence on building domestic brand (Hu). 
3. Public awareness on education and access to educational services has positive influence on building domestic brand (Edu).

4. Satellite advertisement programs have positive influence on building domestic brand (Sad).

5. Advertisement programs through distribution brushers have positive influence on building domestic brand (Lad).

6. Internet advertisement has positive influence on building domestic brand (Iad).

7. Advertisement in foreign journals has positive impact on building domestic brand (Mad).

8. Introducing cultural heritage has positive impact on building domestic brand (Her).

9. Public awareness on economical power has positive impact on building domestic brand (Eco).

10. Public awareness on specialized symposium and conferences has positive impact on building domestic brand (Sem).

The proposed study of this paper designs a questionnaire and distributes it among 384 people who have already visited Iran as tourist. The questionnaire maintains two parts, in the first part we ask them about their personal characteristics and the second part of the survey includes 40 questions on 10 important factors impacting building national brand. Cronbach alpha was calculated for this survey as 0.84 , which is well above the minimum desired level. The first step on examining the data is to test whether the data are normally distributed or not. We also use Kolmogorov - Smirnov test to verify this item. Table 1 shows the results of our test.

\section{Table 1}

The results of Kolmogorov - Smirnov

\begin{tabular}{|c|c|c|c|c|c|c|c|c|c|c|}
\hline Var. & En & $\mathrm{Hu}$ & Edu & Sad & Lad & Iad & Mad & Her & Eco & Sem \\
\hline K-S & 1.84 & 1.95 & 1.34 & 1.28 & 1.88 & 1.54 & 1.80 & 1.24 & 1.37 & 1.19 \\
\hline Sig.2-taild & 0.00 & 0.00 & 0.06 & 0.07 & 0.00 & 0.02 & 0.00 & 0.09 & 0.05 & 0.12 \\
\hline
\end{tabular}

As we can observe from the results of Table 1, we cannot reject the null hypothesis for five hypotheses in five cases when the level of significance is five percent. However, since there are more 30 observations, according to central theorem using we may t-student. Table 2 shows details of our findings,

\section{Table 2}

The results of t-student on all components of hypotheses (degree of freedom $=72$ )

\begin{tabular}{|c|c|c|c|c|c|c|}
\hline \multirow{2}{*}{ Variable } & \multirow[b]{2}{*}{ Mean } & \multirow{2}{*}{$\begin{array}{l}\text { Standard } \\
\text { deviation }\end{array}$} & \multirow{2}{*}{ t-student } & \multirow{2}{*}{ P-value } & \multicolumn{2}{|c|}{ Upper/Lower limits } \\
\hline & & & & & Lower & Upper \\
\hline En & 3.69 & .54207 & 10.87 & 0.00 & 0.56 & 0.82 \\
\hline $\mathrm{Hu}$ & 2.49 & .33378 & -13.03 & 0.00 & -0.59 & -0.43 \\
\hline Edu & 3.18 & .52276 & 2.93 & 0.00 & 0.06 & 0.30 \\
\hline Sad & 2.01 & .63933 & -13.23 & 0.00 & -1.14 & -0.84 \\
\hline Lad & 2.08 & .42707 & -18.36 & 0.00 & -1.02 & -0.82 \\
\hline Iad & 3.12 & .54927 & 2.90 & 0.00 & 0.05 & 0.28 \\
\hline Mad & 2.63 & .47710 & -6.62 & 0.00 & -0.48 & -0.26 \\
\hline Her & 3.57 & .48279 & 10.06 & 0.00 & 0.46 & 0.68 \\
\hline Eco & 2.65 & .39691 & -7.52 & 0.00 & -0.44 & -0.26 \\
\hline Sem & 1.79 & .55955 & -18.41 & 0.00 & -1.34 & -1.07 \\
\hline
\end{tabular}

As we can observe from the results of Table 2, all null hypotheses are rejected and we can conclude that all ten factors influence building national brand. However, these ten components have various impacts on building national brand. In other words, natural attraction has the highest impact followed by advertisement in foreign journals, introducing cultural heritage and internet advertisement. While public awareness on specialized symposium and conferences maintains the lowest impact followed by satellite advertisement programs, advertisement programs through distribution brushers and public awareness on human right. 


\section{Factor analysis}

Factor analysis plays an essential role on detecting important factors and grouping them into smaller groups. Table 3 shows the correlation factors among ten various factors.

Table 3

Correlation data

\begin{tabular}{cccccccccccc}
\hline Components & $\mathrm{Hu}$ & $\mathrm{En}$ & Edu & Sad & Lad & Iad & Mad & Her & Eco & Sem \\
\hline Hu & 1 & .123 & -.181 & .380 & -.021 & .298 & .369 & -.057 & .196 & .004 \\
En & .123 & 1 & -.029 & -.306 & .164 & .142 & .042 & .107 & -.239 & -.433 \\
Edu & -.181 & -.029 & 1 & -.090 & .260 & .037 & -.030 & .547 & .058 & .325 \\
Sad & .380 & -.306 & -.090 & 1 & .162 & .001 & .181 & -.247 & .343 & .173 \\
Lad & -.021 & .164 & .260 & .162 & 1 & -.003 & .104 & .162 & .228 & .406 \\
Iad & .298 & .142 & .037 & .001 & -.003 & 1 & .297 & .288 & -.099 & -.111 \\
Mad & .369 & .042 & -.030 & .181 & .104 & .297 & 1 & -.103 & .147 & .167 \\
Her & -.057 & .107 & .547 & -.247 & .162 & .288 & -.103 & 1 & .041 & -.031 \\
Eco & .196 & -.239 & .058 & .343 & .228 & -.099 & .147 & .041 & 1 & .302 \\
Sem & .004 & -.433 & .325 & .173 & .406 & -.111 & .167 & -.031 & .302 & 1 \\
\hline
\end{tabular}

Before we perform factor analysis we need to make sure they maintain meaningful information using KMO test. Here, the null hypothesis is that all variables have correlation with themselves while the alternative hypothesis specifies that variables do not maintain correlation with themselves. The results of KMO test yields 0.635 , which means there are good correlations among data for factor analysis. In addition, Bartlet test also yields 172.592 with 45 degrees of freedom, which confirms KMO test when the level of significance is one percent. Table 4 shows initial factors with their extraction values.

\section{Table 4}

Common initial values using factor analysis with no rotation

\begin{tabular}{lcccccccccc}
\hline Var. & En & $\mathrm{Hu}$ & $\mathrm{Ed}$ & $\mathrm{Sad}$ & Lad & Iad & Mad & Her & Eco & Ser \\
\hline Initial & 1 & 1 & 1 & 1 & 1 & 1 & 1 & 1 & 1 & 1 \\
Extraction & 0.678 & 0.889 & 0.736 & 0.589 & 0.838 & 0.716 & 0.507 & 0.774 & 0.460 & 0.674 \\
\hline
\end{tabular}

As we can observe from the results of Table 4, for instance, advertisement programs through distribution brushers demonstrates $83 \%$ of common factor. Since most factors maintain more than $50 \%$ of extracted factors, we can conclude that they are suitable as basis for factor analysis. Table 5 shows, the number of extracted factors along with their eigenvalues, percentage of variance and accumulated percentage of variance. Table 5 shows details of our factor analysis using Varimax rotation technique. As we can observe, factors one to four with $20.226 \%, 18.211 \%, 17.496 \%$ and $12.664 \%$, respectively represent $68.597 \%$ of total variance.

Table 5

Factor analysis using Varimax rotation technique

\begin{tabular}{|c|c|c|c|c|c|c|c|c|c|}
\hline \multirow[b]{2}{*}{ Factor } & \multicolumn{3}{|c|}{ Initial Eigenvalues } & \multicolumn{3}{|c|}{$\begin{array}{l}\text { Extraction Sums of Squared } \\
\text { Loadings }\end{array}$} & \multicolumn{3}{|c|}{$\begin{array}{c}\text { Rotation Sums of Squared } \\
\text { Loadings }\end{array}$} \\
\hline & Eig. & \%Var. & \%Aсc. & Eig. & \%Var. & \%Acc. & Eig. & \%Var. & \%Aсc. \\
\hline 1 & 2.188 & 21.881 & 21.881 & 2.188 & 21.881 & 21.881 & 2.023 & 20.226 & 20.226 \\
\hline 2 & 1.912 & 19.118 & 40.999 & 1.912 & 19.118 & 40.999 & 1.821 & 18.211 & 38.437 \\
\hline 3 & 1.723 & 17.228 & 58.227 & 1.723 & 17.228 & 58.227 & 1.750 & 17.496 & 55.933 \\
\hline 4 & 1.037 & 10.370 & 68.597 & 1.037 & 10.370 & 68.597 & 1.266 & 12.664 & 68.597 \\
\hline 5 & .874 & 8.744 & 77.341 & & & & & & \\
\hline 6 & .669 & 6.693 & 84.034 & & & & & & \\
\hline 7 & .574 & 5.744 & 89.778 & & & & & & \\
\hline 8 & .499 & 4.994 & 94.772 & & & & & & \\
\hline 9 & .337 & 3.372 & 98.144 & & & & & & \\
\hline 10 & .186 & 1.856 & 100.000 & & & & & & \\
\hline
\end{tabular}


One of the useful ways to find a suitable level to detect optimum numbers of factors is use Screet plot. According to this plot, when the changes become linear, we may detect the optimal number of factors. Fig. 1 shows Screet plot for the proposed study of this paper.

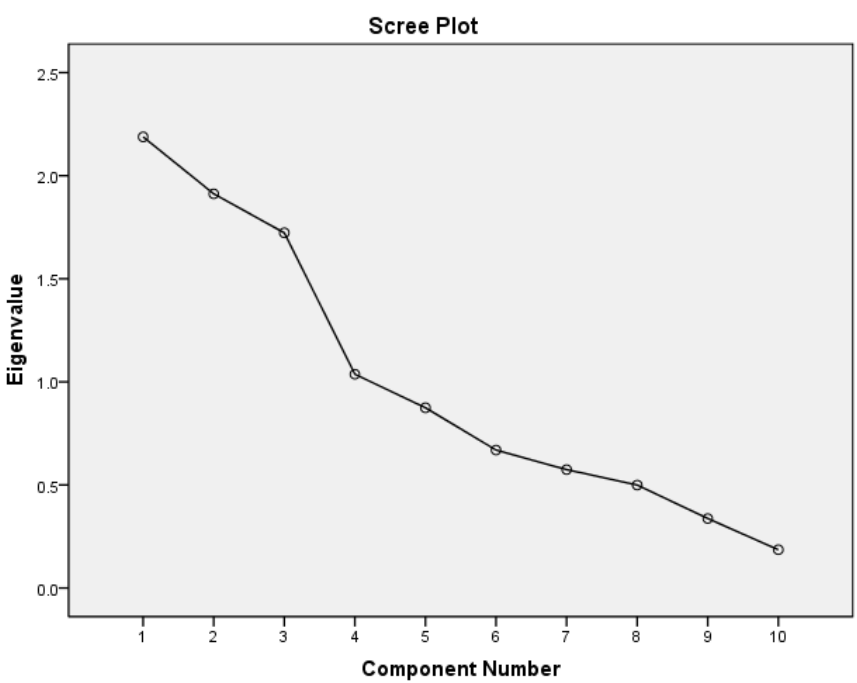

Fig. 1. Screet plot

It is clear from the figure that we can extract four factors. Table 6 shows portions of each factor before rotation is applied.

Table 6

FA before rotation

\begin{tabular}{ccccc}
\hline Variable & 1st & 2nd & 3rd & 4th \\
\hline Hu & .389 & -.480 & .542 & -.046 \\
En & -.456 & -.001 & .551 & .615 \\
Edu & .173 & .814 & .141 & -.154 \\
Sad & .672 & -.366 & -.046 & -.035 \\
Lad & .454 & .438 & .160 & .643 \\
Iad & .014 & -.037 & .762 & -.366 \\
Mad & .435 & -.265 & .496 & .025 \\
Her & -.087 & .702 & .436 & -.288 \\
Eco & .673 & .030 & -.073 & .026 \\
Sem & .701 & .356 & -.236 & .010 \\
Hu & .389 & -.480 & .542 & -.046 \\
\hline
\end{tabular}

Table 7

FA after Verimax rotation and normalization

\begin{tabular}{ccccc}
\hline Variable & 1st & 2nd & 3rd & 4th \\
\hline Hu & .075 & .802 & -.172 & .010 \\
En & -.788 & .181 & -.014 & .485 \\
Edu & .207 & -.152 & .789 & .216 \\
Sad & .574 & .394 & -.319 & .049 \\
Lad & .195 & .037 & .170 & .877 \\
Iad & -.215 & .676 & .414 & -.202 \\
Mad & .135 & .681 & -.040 & .150 \\
Her & -.117 & .045 & .870 & .029 \\
Eco & .607 & .193 & -.024 & .231 \\
Sem & .734 & -.066 & .187 & .308 \\
Hu & .075 & .802 & -.172 & .010 \\
\hline
\end{tabular}

The numbers are within -1 to +1 and once they get close their border numbers the factors are more important. Table 7 demonstrates the factor analysis after rotation is applied. Based on the results of Table 7, the first factor includes three most important components including Satellite advertisement programs, public awareness on economical power and public awareness on specialized symposium and conferences. The second factor includes three other important factors, which are public awareness on human right, advertisement programs through distribution brushers and internet advertisement. The third factor includes two variables, which are public awareness on education and access to educational services and introducing cultural heritage. Finally, the last factor includes introducing natural attraction and advertisement programs through distribution brushers. Finally, Table 8 shows details the correlation matrix among four variables.

Based on the results we have accomplished from Table 8, the first factor is associated with providing awareness in non-written form in other countries while the second factor is associated with written form of advertisement in other countries. The third factor is associated with awareness on Iranian culture and the last factor is related to natural attractions of this factor. Although some other factors 
such as human rights and economical conditions are also important factors but since Iran is located in special geopolitical region it could impact all factors either directly or indirectly.

Table 8

Correlation matrix among four factors

\begin{tabular}{ccccc}
\hline Factors & First & Second & Third & Fourth \\
\hline First & .863 & .398 & -.015 & .312 \\
Second & .094 & -.434 & .831 & .336 \\
Third & -.421 & .798 & .398 & .165 \\
Fourth & -.265 & -.126 & -.389 & .873 \\
\hline
\end{tabular}

In summary, we can conclude that Iranian advertisement techniques outside the country play the least important impact on building national brand and they are not properly implemented. In fact, many tourists receive their information through different social pages, historical monuments, natural attractions and these are main sources of their awareness for traveling to Iran. Many people claim they had little information on Iran prior to their trip but their trip to Iran significantly added to their awareness. This could simply show that government programs did not have good impact on people's motivation for travelling to Iran.

\section{Conclusion}

In this paper, we have presented an empirical study to find important factors influencing people for traveling to Iran as tourists. The proposed study designed a questionnaire and distributed among different people and using factor analysis detected important factors in four groups. Based on the results of this study, the first factor includes three most important components including Satellite advertisement programs, public awareness on economical power and public awareness on specialized symposium and conferences. The second factor includes three other important factors, which are public awareness on human right, advertisement programs through distribution brushers and internet advertisement. The third factor includes two variables, which are public awareness on education and access to educational services and introducing cultural heritage. Finally, the last factor includes introducing natural attraction and advertisement programs through distribution brushers. The results also indicated that Iranian advertisement techniques outside the country play the least important impact on building national brand and they are not properly implemented. In fact, many tourists received their information through different social pages, historical monuments, natural attractions and these are main sources of their awareness for traveling to Iran.

\section{Acknowledgment}

The authors would like to thank the people who participated in our survey and carefully answered all our questions. We are also delighted for constructive comments on earlier version of this paper, which have contributed to this paper.

\section{References}

Aaker, D. A. (1991). Managing Brand Equity. New York: The Free Press.

Aaker, D. A. (1996). Building Strong Brands. New York: The Free Press.

Aaker, D. A., \& Shansby, J. G. (1982). Positioning your product. Business Horizons, 25(3), 56-62.

Aaker, J. L. (1997). Dimensions of brand personality. Journal of Marketing Research, 34(3), 347.

Anholt, S. (2002). Nation Branding: A continuing theme. Journal of Brand Management, 10(1), 59.

Baloglu, S. (1996). An empirical investigation of determinants of tourist destination image. Unpublished dissertation. Virginia Polytechnic University, Blacksburg, Virginia.

Baloglu, S., \& Brinberg, D. (1997). Affective images of tourism destination. Journal of Travel Research, 35(4), 11-15. 
Baloglu, S., \& Mangaloglu, M. (2001). Tourism destination images of Turkey, Egypt, Greece, and Italy as perceived by US-based tour operators and travel agents. Tourism Management, 22(1), 1-9.

Baloglu, S., \& McCleary, K. (1999). A model of destination image formation. Annals of Tourism Research, 26(4), 868-897.

Cai, A. (2002). Cooperative branding for rural destinations. Annals of Tourism Research, 29(3), 720742.

Cai, L. A., Feng, R., \& Breiter, D. (2004). Tourist purchase decision involvement and information preferences. Journal of Vacation Marketing, 10(2), 138-148.

Caldwell, N., \& Freire, J. R. (2004). The differences between branding a country, a region and a city: Applying the Brand Box Model. Journal of Brand Management, 12(1), 50-61.

Cronbach, L. J. (1951). Coefficient alpha and the internal structure of tests. Psychometrika, 16, 297334.

Cronbach, L. J., \& Meehl, P. E. (1955). Construct validity in psychological tests. Psychological Bulletin, 52, 281-302.

Gilmore, F. (2002). A country--can it be repositioned? Spain--the success story of country branding. Journal of Brand Management, 9(4/5), 281.

Hall, D. (2002). Brand development, tourism and national identity: The re-imaging of former Yugoslavia. Journal of Brand Management, 9(4/5), 323.

Harrison, S. (2002). Culture, tourism and local community--the heritage identity of the Isle of Man. Journal of Brand Management, 4/5, 355.

Florek, M. (2005). The country brand as a new challenge for Poland. Place Branding, 1(2), 205-214.

Florek, M., Insch, A., \& Gnoth, J. (2006). City council websites as a means of place brand identity communication. Place Branding, 2(4), $276 \mathrm{e} 296$.

Kapferer, J. (1997). Strategic brand management. Great Britain: Kogan Page.

Keller, K. L. (1993). Conceptualizing, measuring, and managing customer-based brand equity. Journal of Marketing, 57(1), 1e22.

Keller, K. L. (2008). Strategic Brand Management: Building, Measuring, and Managing Brand Equity (3rd ed.). New Jersey: Prentice Hall.

Kleppe, I. A., Iversen, N. M., \& Stensaker, I. G. (2002). Country images in marketing strategies: Conceptual issues and an empirical Asian illustration. Journal of Brand Management, 10(1), 61.

Kotler, P., \& Gertner, D. (2002). Country as brand, products, and beyond: A place marketing and brand management perspective. Journal of Brand Management, 9(4/5), 249.

Kotler, P. H. (1991). Marketing Management: Analysis, Planning, and Control (8 ed.). Englewood Cliffs, NJ: Prentice-Hall, Inc.

Kra, P. (2002). The concept of national character in 18th century France [Electronic Version]. Cromohs, 1-6. Retrieved February 18, 2007 from http://www.cromohs.unifi.it/7 2002/kra.html\#np1

Lodge, C. (2002). Success and failure: The brand stories of two countries. Journal of Brand Management, 9(4/5), 372.

Mathieson,A. and Wall,G. (1982) Tourism: Economic, Physical and Social Impacts. Longman, Harlow.

Middleton, V.(1994) Marketing in Travel and Tourism, $2^{\text {nd }}$ edition, Butterworth-Heinemann, Oxford

Mill, R.C, \& Morrison A.M. (1992) The Tourism System, $2^{\text {nd }}$ edition, Prentice Hall International, London

Morgan, N., Pritchard, A., \& Piggott, R. (2002). New Zealand, 100\% Pure. The creation of a powerful niche destination brand. Journal of Brand Management, 9(4/5), 335.

Paswan, A. K., Kulkarni, S., \& Ganesh, G. (2003). Nation Branding Loyalty towards the country, the state and the service brands. Journal of Brand Management, 10(3), 233.

Pike, S. (2009). Destination brand positions of a competitive set of near-home destinations. Tourism Management, 30(6), 857-866. 
Ryan, C., \& Gu, H. (2008). Destination branding and marketing: the role of marketing organizations. In H. Oh (Ed.), Handbook of hospitality marketing management (pp. 383-411). Oxford: Butterworth-Heinemann.

Starr, A. (2001). Charlotte Beers’ toughest sell [Electronic Version]. Business Week Online.

Tabrizi, N., Taghvaei, M., \& Varesi, H.R. (2012). A fuzzy application on MICE hosting: An Iranian case study for locating suitable areas based on P.L Indexes. Management Science Letters, 2(2), 503-510.

Zarabi, A., \& Ahmadi, D. (2012). Ranking different cities and villages in province of Isfahan based of analysis of social indicator during the statistic period 1996-2006. Management Science Letters, 2(6), 2077-2084. 